\title{
Optimizing Ligand Efficiency of Selective Androgen Receptor Modulators (SARMs)
}

\author{
Anthony L. Handlon, ${ }^{*}$ Lee T. Schaller, Lisa M. Leesnitzer, ${ }^{\dagger}$ Raymond V. Merrihew, Chuck Poole, \\ John C. Ulrich, Joseph W. Wilson, Rodolfo Cadilla, and Philip Turnbull
}

Metabolic Pathways Cardiovascular Unit and Platform Technology \& Science, GlaxoSmithKline, 709 Swedeland Road, King of Prussia, Pennsylvania 19406-0939, United States

Supporting Information

ABSTRACT: A series of selective androgen receptor modulators (SARMs) containing the 1-(trifluoromethyl)benzyl alcohol core have been optimized for androgen receptor (AR) potency and drug-like properties. We have taken advantage of the lipophilic ligand efficiency (LLE) parameter as a guide to interpret the effect of structural changes on AR activity. Over the course of optimization efforts the LLE increased over 3 log units leading to a SARM 43 with nanomolar potency, good aqueous kinetic solubility $(>700 \mu \mathrm{M})$, and high oral bioavailability in rats $(83 \%)$.

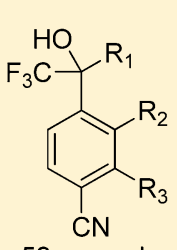

52 examples

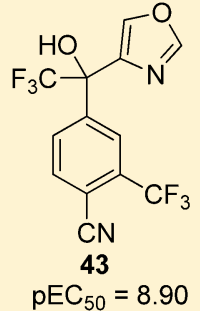

$\operatorname{cog} \mathrm{P}=1.22$

$\mathrm{LLE}=7.68$

solubility $>700 \mu \mathrm{M}$

oral $\mathrm{F}=83 \%, \mathrm{t}_{1 / 2}=8 \mathrm{~h}$

KEYWORDS: ligand efficiency, LLE, androgen receptor, selective androgen receptor modulator, SARM

S keletal muscle represents approximately $70 \%$ of body cell mass in the adult, ${ }^{1}$ and the maintenance of this tissue depends upon a finely tuned balance between catabolic and anabolic processes. Under certain conditions this balance is skewed in favor of catabolism. Patients with diseases such as cancer, AIDS, chronic kidney disease, COPD, or chronic heart failure often become catabolic resulting in the rapid loss of skeletal muscle tissue. The consequences of muscle wasting disease are manifold. The loss of muscle associated with disease (also known as cachexia) is correlated with poorer clinical prognosis, lower quality of life for the patient, and higher overall mortality rates. ${ }^{2}$

Even in the absence of disease, advancing age can bring on a $1-2 \%$ loss of lean muscle tissue per year. ${ }^{3}$ The gradual decline of muscle mass and function associated with aging (also known as sarcopenia) leads to a loss of mobility and balance, which can lead to serious falls and extended hospital stays. Furthermore, because muscle is the largest metabolically active tissue in the body, loss of muscle leads to lower energy expenditure and an increase in metabolic diseases such as obesity and diabetes. ${ }^{1}$ New evidence has emerged that maintaining skeletal muscle through resistance training decreases central adiposity ${ }^{4}$ the accumulation of which is associated with the development of lipid disorders, insulin resistance, and hypertension. ${ }^{1}$

There are few clinically validated molecular targets for tipping the balance in favor of muscle anabolism. ${ }^{5}$ One of the oldest known and most familiar anabolic targets is the androgen receptor (AR). Early work on the physiological effects of androgens dates back to $1889,{ }^{6}$ but it was not until the early<smiles>CC12CCC(=O)C=C1CCC1C2CCC2(C)C(O)CCC12</smiles><smiles></smiles><smiles>CC1CNS(=O)(=O)N(c2ccc3c(C#N)nccc3c2)C1</smiles><smiles>Cc1c(C(C)(C)C(O)C(F)(F)F)ccc(C#N)c1C(F)(F)F</smiles><smiles>CC(O)(c1ccc(C#N)c(C(F)(F)F)c1C(F)(F)F)C(F)(F)F</smiles>

Figure 1. Structures of testosterone and selected SARMs.

20th century that the natural ligand, testosterone (1, Figure 1), was isolated. A metabolite of testosterone, dihydrotestosterone,

Received: September 29, 2015

Accepted: November 19, 2015

Published: November 19, 2015 
Scheme 1. Synthesis of Truncated SARMs $6-54^{a}$

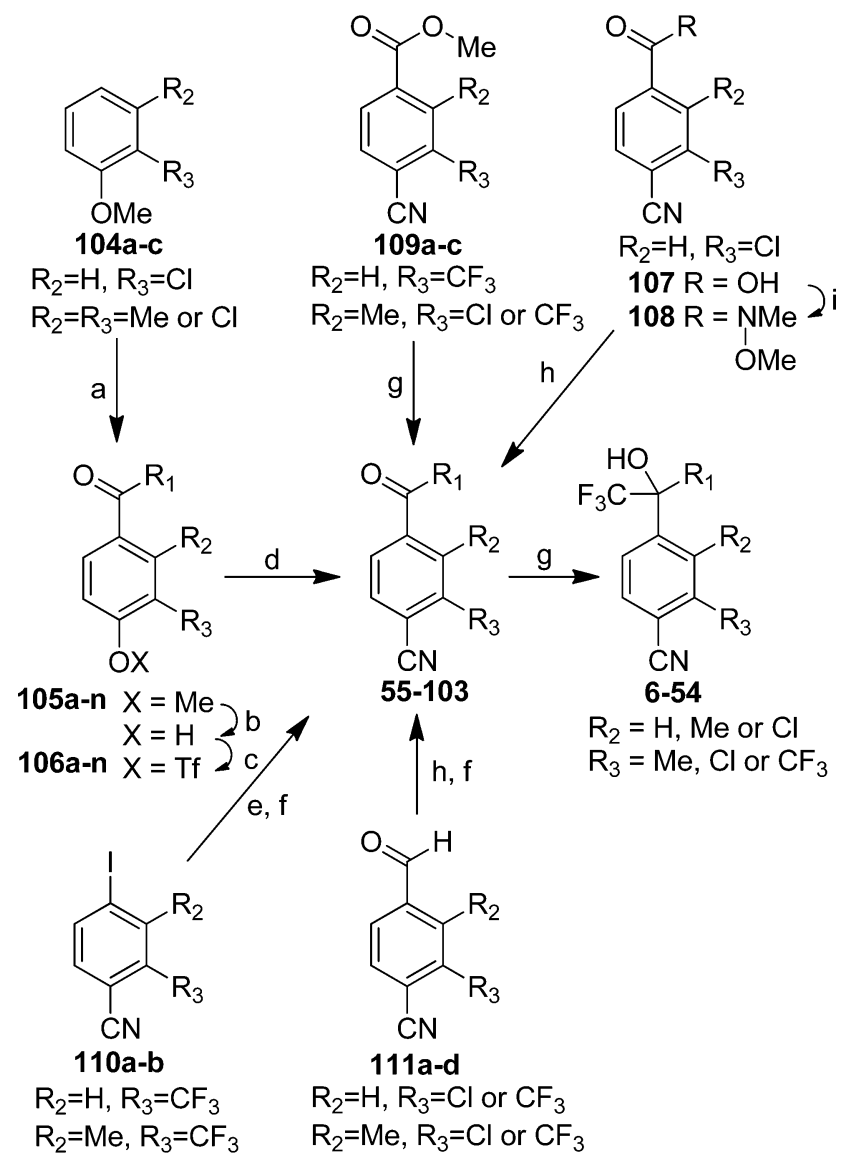

${ }^{a}$ Reagents and conditions: (a) $\mathrm{R}_{1} \mathrm{COCl}, \mathrm{AlCl} 1_{3}, \mathrm{DCM}, \mathrm{RT}$; (b) $\mathrm{AlCl}_{3}$, heptane. $105{ }^{\circ} \mathrm{C}$; (c) triflic anhydride, $\mathrm{NEt}_{3}, \mathrm{DCM}, \mathrm{RT}$; (d) zinc cyanide, $\left[\mathrm{P}(\mathrm{Ph})_{3}\right]_{4} \mathrm{Pd}(0), \mathrm{DMF}, 110{ }^{\circ} \mathrm{C}$; (e) isopropylmagnesium bromide or $n$-BuLi, THF, $-78{ }^{\circ} \mathrm{C}$, then $\mathrm{R}_{1} \mathrm{CHO}$; (f) Dess-Martin periodinane or pyridinium chlorochromate, DCM, RT; $(\mathrm{g}) \mathrm{CF}_{3} \mathrm{Si}$ $(\mathrm{Me})_{3}, \mathrm{CsF}$, then TBAF, THF, RT; (h) $\mathrm{R}_{1} \mathrm{MgBr}$ or terminal alkyne, $\mathrm{ZnCl}_{2}, \mathrm{NEt}_{3}, \mathrm{THF}, 0{ }^{\circ} \mathrm{C}$; (i) $\mathrm{N}$-methyl-O-methylhydroxylamine hydrochloride, HATU, DMF, RT.

is also an AR ligand and is a more potent activator than testosterone itself. The androgen receptor (AR) is a nuclear hormone receptor that is present in many tissues of the body and is involved in a variety of physiological processes. The recent discovery of selective androgen receptor modulators (SARMs) has enabled the tissue-selective stimulation of anabolic effects in muscle while avoiding stimulation of the prostate gland and masculinization (virilization) effects that can be associated with steroid hormone therapy. There are excellent review articles on SARMs which explain their mechanism of action, SAR, and potential for therapeutic value. ${ }^{7,8}$

Currently SARMS are the subject of several clinical investigations for their ability to improve muscle strength, bone density, and functional performance. Enobosarm (also known as Ostarine, MK-2866, GTx-024, 2, Figure 1) is in Phase III trials for the prevention and treatment of muscle wasting in patients with nonsmall cell lung cancer (NSCLC). It has been shown to improve stair climb performance and quality of life (QOL) in patients with cancer cachexia. ${ }^{9}$ In a Phase II trial, this compound was found to improve lean body mass and physical functioning in aging men and women. ${ }^{10}$ LGD-4033 ${ }^{11}$ (Ligandrol, 3) is entering Phase II development for the
Scheme 2. Synthesis of Diol 115 and Constrained Analogues 118 and $121^{a}$

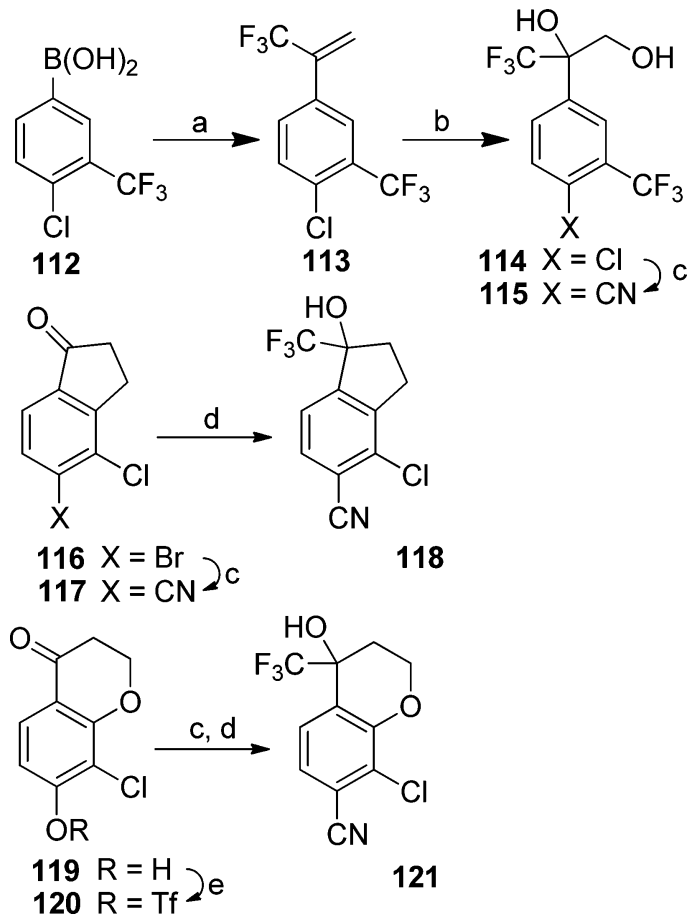

${ }^{a}$ Reagents and conditions: (a) 2-bromo-3,3,3-trifluoropropene, $\mathrm{Na}_{2} \mathrm{CO}_{3}, \mathrm{Cl}_{2}\left[\mathrm{P}(\mathrm{Ph})_{3}\right]_{2} \mathrm{Pd}(\mathrm{II}) \mathrm{DME}, \mathrm{H}_{2} \mathrm{O}, 80{ }^{\circ} \mathrm{C}, 62 \%$; (b) Nmethylmorpholine- $\mathrm{N}$-oxide, $\mathrm{OsO}_{4}$, acetone, $\mathrm{H}_{2} \mathrm{O}, \mathrm{RT}, 54 \%$; (c) $\mathrm{Zn}(\mathrm{CN})_{2},\left[\mathrm{P}(\mathrm{Ph})_{3}\right]_{4} \mathrm{Pd}(0)$, DMF, $110-150{ }^{\circ} \mathrm{C}, 76 \%$; (d) $\mathrm{CF}_{3} \mathrm{Si}(\mathrm{Me})_{3}$, CsF, then TBAF, THF, RT, 57\%; (e) triflic anhydride, $\mathrm{NEt}_{3}, \mathrm{DCM}, 0$ ${ }^{\circ} \mathrm{C}, 93 \%$.

treatment of muscle wasting associated with cancer. Pfizer has recently disclosed SARM PF-14 (4), which has completed Phase I clinical studies and will be advanced to Phase II investigations for the treatment of cachexia. ${ }^{12-14}$

Our project's goal was to discover small and drug-like compounds with high potency in an AR functional activation assay, high ligand efficiency, good solubility and excellent PK properties. We were exploring a series of compounds exemplified by 5 (Figure $1, \mathrm{AR}_{\mathrm{pEC}} \mathrm{E}_{50}=7.80, \operatorname{clogP}=3.47$ ) in which the headgroup was attached to the aromatic ring through carbon instead of nitrogen as is seen with $\mathbf{2 , 3}$, and 4 . In the course of our studies we truncated the headgroup of 5 by moving in the $\mathrm{CF}_{3}$ and $\mathrm{OH}$ groups to the benzylic carbon resulting in compound $6\left(\mathrm{pEC}_{50}=8.40, \operatorname{clogP}=2.95\right)$. This structural change provided a compound with greater SARM potency, lower molecular weight, and lower clogP. The truncated analogue 6 was significantly more compact than previous SARM compounds and represented an attractive starting point for discovering novel SARMs with superior druglike properties. Herein we report our investigations into the synthesis and optimization of 1-trifluoromethyl-4-cyanobenzyl alcohol analogues of compound 6 . We have taken advantage of one of the ligand efficiency metrics, namely, the lipophilic ligand efficiency (LLE), to gain a deeper understanding of the effect of structural changes in the series.

The synthesis of the 1-trifluoromethyl-4-cyanobenzyl alcohols (6-54, Scheme 1) was accomplished by trifluoromethylation of the appropriately substituted 4-cyanophenyl ketones (55-103), which were constructed using a variety of 
Table 1. Androgen Receptor Activity, clogP, and Lipophilic Ligand Efficiency (LLE) of SARMs ${ }^{a}$<smiles>[R6]c1c(C#N)ccc(C([R])(O)F)c1[R]</smiles>

\begin{tabular}{|c|c|c|c|c|c|c|c|c|c|c|c|c|c|}
\hline & $\mathbf{R}_{1}$ & $\mathbf{R}_{\mathbf{2}}$ & $\mathbf{R}_{\mathbf{3}}$ & $\mathrm{pEC}_{50}$ & $\operatorname{clog} P$ & LLE & & $\mathbf{R}_{1}$ & $\mathbf{R}_{\mathbf{2}}$ & $\mathbf{R}_{\mathbf{3}}$ & $\mathrm{pEC}_{50}$ & $\operatorname{clog} P$ & LLE \\
\hline 6 & methyl & $\mathrm{Me}$ & $\mathrm{CF}_{3}$ & 8.40 & 2.95 & 5.45 & 24 & t-butyl & $\mathrm{H}$ & $\mathrm{Cl}$ & 6.80 & 3.53 & 3.27 \\
\hline 7 & $\mathrm{CF}_{3}$ & $\mathrm{Me}$ & $\mathrm{CF}_{3}$ & 8.80 & 3.51 & 5.29 & 25 & cyclopropyl & $\mathrm{H}$ & $\mathrm{Cl}$ & 9.40 & 2.65 & 6.75 \\
\hline 8 & isopropyl & $\mathrm{Me}$ & $\mathrm{CF}_{3}$ & 9.60 & 3.88 & 5.72 & 26 & cyclobutyl & $\mathrm{H}$ & $\mathrm{Cl}$ & 8.80 & 3.20 & 5.60 \\
\hline 9 & cyclopropyl & $\mathrm{Me}$ & $\mathrm{CF}_{3}$ & 10.50 & 3.40 & 7.10 & 27 & cyclopentyl & $\mathrm{H}$ & $\mathrm{Cl}$ & 8.50 & 3.76 & 4.74 \\
\hline 10 & cyclobutyl & $\mathrm{Me}$ & $\mathrm{CF}_{3}$ & 9.70 & 3.95 & 5.75 & 28 & methyl & $\mathrm{Cl}$ & $\mathrm{Cl}$ & 7.20 & 2.80 & 4.40 \\
\hline 11 & $\mathrm{CF}_{3}$ & $\mathrm{H}$ & $\mathrm{CF}_{3}$ & 7.80 & 3.07 & 4.73 & 29 & ethyl & $\mathrm{Cl}$ & $\mathrm{Cl}$ & 8.60 & 3.32 & 5.28 \\
\hline 12 & ethyl & $\mathrm{H}$ & $\mathrm{CF}_{3}$ & 8.40 & 3.03 & 5.37 & 30 & isopropyl & $\mathrm{Cl}$ & $\mathrm{Cl}$ & 9.10 & 3.72 & 5.38 \\
\hline 13 & isopropyl & $\mathrm{H}$ & $\mathrm{CF}_{3}$ & 8.10 & 3.43 & 4.67 & 31 & cyclopropyl & $\mathrm{Cl}$ & $\mathrm{Cl}$ & 9.70 & 3.24 & 6.46 \\
\hline 114 & $\mathrm{CH}_{2} \mathrm{OH}$ & $\mathrm{H}$ & $\mathrm{CF}_{3}$ & 5.00 & 1.64 & 3.36 & 32 & cyclobutyl & $\mathrm{Cl}$ & $\mathrm{Cl}$ & 9.20 & 3.80 & 5.40 \\
\hline 14 & cyclopropyl & $\mathrm{H}$ & $\mathrm{CF}_{3}$ & 9.80 & 2.95 & 6.85 & 33 & isobutyl & $\mathrm{Cl}$ & $\mathrm{Cl}$ & 8.50 & 4.25 & 4.25 \\
\hline 15 & cyclobutyl & $\mathrm{H}$ & $\mathrm{CF}_{3}$ & 8.80 & 3.50 & 5.30 & 34 & neopentyl & $\mathrm{Cl}$ & $\mathrm{Cl}$ & 8.50 & 4.65 & 3.85 \\
\hline 16 & $\mathrm{CH}=\mathrm{CH}_{2}$ & $\mathrm{H}$ & $\mathrm{CF}_{3}$ & 7.90 & 2.75 & 5.15 & 35 & $\mathrm{CF}_{3}$ & $\mathrm{Me}$ & $\mathrm{Cl}$ & 7.70 & 3.21 & 4.49 \\
\hline 17 & $\mathrm{C}\left(=\mathrm{CH}_{2}\right) \mathrm{CH}_{3}$ & $\mathrm{H}$ & $\mathrm{CF}_{3}$ & 7.50 & 3.15 & 4.35 & 36 & ethyl & $\mathrm{Me}$ & $\mathrm{Cl}$ & 8.70 & 3.18 & 5.52 \\
\hline 18 & $\mathrm{C}\left(\mathrm{CH}_{3}\right)=\mathrm{CHCH}_{3}$ & $\mathrm{H}$ & $\mathrm{CF}_{3}$ & 7.40 & 3.68 & 3.72 & 37 & isopropyl & $\mathrm{Me}$ & $\mathrm{Cl}$ & 9.10 & 3.58 & 5.52 \\
\hline 19 & methyl & $\mathrm{Me}$ & $\mathrm{Me}$ & 5.60 & 2.66 & 2.94 & 38 & cyclopropyl & $\mathrm{Me}$ & $\mathrm{Cl}$ & 9.70 & 3.09 & 6.61 \\
\hline 20 & isopropyl & $\mathrm{Me}$ & $\mathrm{Me}$ & 7.90 & 3.59 & 4.31 & 39 & t-butyl & $\mathrm{Me}$ & $\mathrm{Cl}$ & 7.10 & 3.98 & 3.12 \\
\hline 21 & cyclopropyl & $\mathrm{Me}$ & $\mathrm{Me}$ & 8.80 & 3.10 & 5.70 & 40 & neopentyl & $\mathrm{Me}$ & $\mathrm{Cl}$ & 8.40 & 4.51 & 3.89 \\
\hline 22 & neopentyl & $\mathrm{Me}$ & $\mathrm{Me}$ & 7.70 & 4.51 & 3.19 & 41 & $\mathrm{C} \equiv \mathrm{C}-\mathrm{t}-\mathrm{butyl}$ & $\mathrm{Me}$ & $\mathrm{Cl}$ & 7.10 & 3.80 & 3.30 \\
\hline 23 & isopropyl & $\mathrm{H}$ & $\mathrm{Cl}$ & 8.40 & 3.13 & 5.27 & 42 & $\mathrm{C} \equiv \mathrm{C} \longrightarrow$ & $\mathrm{Me}$ & $\mathrm{Cl}$ & 7.80 & 4.68 & 3.12 \\
\hline
\end{tabular}

$a_{\mathrm{pEC}_{50}}$ results represent $-\log \left(\mathrm{EC}_{50}\right)$ androgen receptor $(\mathrm{AR})$ functional activities, which were determined via a luciferase reporter gene assay using mammalian cells transfected with the human AR gene. For complete assay details, see the Supporting Information section. Values for clogP were calculated using the Daylight Chemical Information Systems model. LLE $=\mathrm{pEC}_{50}-\operatorname{clog} \mathrm{P}$.

approaches. One versatile method was via highly regioselective Friedel-Crafts acylation of appropriately substituted anisoles $(104 a-c)$. The resulting 4-acyl anisoles $(105 a-n)$ were then demethylated and converted to the corresponding 4-acyl benzonitriles by way of the triflate intermediates $(106 a-n)$. Still another approach started with appropriately substituted benzoic acid (107), which was converted to the Weinreb amide (108) and then reacted with Grignard reagents to give the necessary 4-cyanophenyl ketones. ${ }^{15}$ In other cases methyl-4cyanobenzoates $(109 \mathbf{a}-\mathbf{c})$ were reacted with Ruppert's reagent to give trifluoromethyl ketones. ${ }^{16}$ In another approach 4iodobenzonitriles $(\mathbf{1 1 0 a}, \mathbf{b})$ were subjected to halogen-lithium exchange followed by reaction with an aldehyde to give a phenyl carbinol intermediate, which was oxidized to the corresponding 4-cyanophenyl ketone. Alternatively, 4-formyl benzonitriles $(\mathbf{1 1 1 a}-\mathbf{d})$ could be alkylated with Grignard reagents or alkyl zinc reagents followed by oxidation to give the 4-cyanophenyl ketones. Once the central 4-cyanophenylketones $(55-103)$ were in hand they were subjected to trifluoromethylation using Ruppert's reagent (trimethylsilyltrifluoromethylsilane), which reliably afforded the trifluoromethyl carbinol targets $(6-54){ }^{17}$

An alternative approach to introducing the trifluoromethyl group involved a palladium-mediated cross-coupling between a phenylboronic acid (112) and a trifluoromethylbromoalkene ${ }^{18}$ (Scheme 2). The resulting trifluoromethylstyrene (113) was then subjected to oxidation to give 114 followed by cyanation to give the vicinal diol (115). In addition two bicyclic analogues were prepared (Scheme 2). Indanone $116^{19}$ was subjected to cyanation to give ketone 117 and subsequently converted to bicyclic analogue 118. Similarly chromanone intermediate $119^{20}$ was converted to the triflate ester 120 followed by cyanation and trifluoromethylation to give the bicyclic target 121.

Lipophilic ligand efficiency (LLE) is a drug optimization metric that has received increasing use in recent years. ${ }^{21}$ It is defined as the arithmetic difference between $\mathrm{pEC}_{50}$ and clogP (i.e., $\mathrm{LLE}=\mathrm{pEC}_{50}-\operatorname{clog} \mathrm{P}$ ). It is a useful parameter because it 
Table 2. Androgen Receptor Activity, clogP, and Lipophilic Ligand Efficiency (LLE) of Heterocyclic SARMs ${ }^{a}$<smiles>[R]c1c(C#N)ccc(C([R])(O)C(F)(F)F)c1[R]</smiles>

\begin{tabular}{|c|c|c|c|c|c|c|}
\hline & $\mathbf{R}_{1}$ & $\mathbf{R}_{\mathbf{2}}$ & $\mathbf{R}_{\mathbf{3}}$ & $\mathrm{pEC}_{50}$ & $\operatorname{clog} P$ & LLE \\
\hline 43 & & $\mathrm{H}$ & $\mathrm{CF}_{3}$ & 8.90 & 1.22 & 7.68 \\
\hline 44 & & $\mathrm{H}$ & $\mathrm{CF}_{3}$ & 8.90 & 2.71 & 6.19 \\
\hline 45 & & $\mathrm{H}$ & $\mathrm{CF}_{3}$ & 8.70 & 1.89 & 6.81 \\
\hline 46 & & $\mathrm{H}$ & $\mathrm{CF}_{3}$ & 8.70 & 1.89 & 6.81 \\
\hline 47 & & $\mathrm{H}$ & $\mathrm{CF}_{3}$ & 8.60 & 3.43 & 5.17 \\
\hline 48 & & $\mathrm{H}$ & $\mathrm{CF}_{3}$ & 7.70 & 3.94 & 3.76 \\
\hline 49 & & $\mathrm{Me}$ & $\mathrm{CF}_{3}$ & 7.98 & 2.33 & 5.65 \\
\hline 50 & & $\mathrm{Me}$ & $\mathrm{CF}_{3}$ & 8.23 & 2.33 & 5.90 \\
\hline 51 & & $\mathrm{Me}$ & $\mathrm{CF}_{3}$ & 9.30 & 1.67 & 7.63 \\
\hline 52 & & $\mathrm{Me}$ & $\mathrm{CF}_{3}$ & 9.60 & 3.17 & 6.43 \\
\hline 53 & & $\mathrm{Me}$ & $\mathrm{CF}_{3}$ & 8.25 & 4.39 & 3.86 \\
\hline 54 & & $\mathrm{Me}$ & $\mathrm{CF}_{3}$ & 8.54 & 3.88 & 4.66 \\
\hline
\end{tabular}

${ }_{\mathrm{pEC}} \mathrm{p}_{50}$ results represent $-\log \left(\mathrm{EC}_{50}\right)$ androgen receptor (AR) functional activities, which were determined via a luciferase reporter gene assay using mammalian cells transfected with the human AR gene. For complete assay details, see the Supporting Information section. Values for clogP were calculated using the Daylight Chemical Information Systems model. LLE $=\mathrm{pEC}_{50}-\operatorname{clog} \mathrm{P}$.

allows the medicinal chemist to understand the contribution of individual structural changes and to distinguish between those changes that increase receptor activity due to partitioning from an aqueous to a nonaqueous milieu versus a change in receptor activity that is specific for the receptor of interest. The medicinal chemist should find that the lead optimization process results in compounds with greater LLE relative to where one started. As a rough guide medicinal compounds in drug-like space have LLE values in the range $5-7 .{ }^{22}$

As a starting point in our quest to discover novel and ligand efficient SARMs, we were interested in lead 6 (Figure 1). Compound 6 possessed many of the structural features commonly associated with SARMs but was more compact than other known SARM compounds. Replacing the methyl group of $\mathbf{6}$ with a trifluoromethyl gave compound 7 (Table 1), which had greater SARM potency, but lower ligand efficiency owing to the lipophilicity of the CF3 group. We next turned to the isopropyl substituent $(\mathbf{8})$, which boosted the potency to the subnanomolar range. The slightly more compact cyclopropyl analogue (9) afforded a SARM with 32 picomolar potency and an LLE above 7 . This analogue had moderate kinetic aqueous solubility $(245 \mu \mathrm{M}, \mathrm{pH} 7.4),{ }^{23}$ moderate oral bioavailability $(37 \%)$, and a $10 \mathrm{~h}$ half-life following oral dosing in the rat at 10 $\mathrm{mg} / \mathrm{kg}$.

We also explored analogues of $\mathbf{6}$ in which the R2 substituent was eliminated giving 11-18 (Table 1). The extra reach of the ethyl (12) and isopropyl (13) groups relative to the trifluoromethyl (11) allowed greater interaction with a putative lipophilic pocket and the AR potencies increased. However, due to the higher $\operatorname{cog} \mathrm{P}$ of 13 , its ligand efficiency decreased relative to 11. Compound $\mathbf{1 2}$ demonstrated good oral bioavailability in the rat $(70 \%)$, low IV clearance, and an exceedingly long oral half-life of $83 \mathrm{~h}$. In order to lower the clogP and to introduce a potential site for secondary metabolism, we made vicinal diol 114 (Scheme 2). Unfortunately, the receptor did not tolerate the extra polarity in this position, and the compound lacked any measurable AR activity. Small, cyclic substituents as in $\mathbf{1 4}$ and 15 increased AR potency. The cyclopropyl analogue 14 displayed subnanomolar potency and an LLE approaching 7, and it was an order of magnitude more potent than the cyclobutyl analogue 15. In addition, compound 14 possessed good oral bioavailability $(F=86 \%)$ and a $20 \mathrm{~h}$ half-life following oral dosing in the rat. Alkenyl substituted analogues 16-18 explored alternative geometries of the R1 substituent but were not as potent as the corresponding alkyl substituted analogues.

We wished to drive the molecular weights lower so we eliminated the $\mathrm{CF}_{3}$ group from the benzene ring and replaced it with chloro and methyl giving analogues 19-27 (Table 1) all of which had MW < 300. Overall, the SAR followed the trends in potency observed previously: methyl < isopropyl < cyclobutyl < cyclopropyl. Introducing a cyclopentane ring in 27 was detrimental relative to the cyclobutane and cyclopropane substituted analogues $\mathbf{2 5}$ and 26. Forming an additional ring from the benzylic carbon back to the benzene ring to form bicyclic derivatives $118\left(\mathrm{pEC}_{50}=5.00\right)$ and $121\left(\mathrm{pEC}_{50}=6.00\right.$, Scheme 2) locked the geometry of the trifluoromethyl carbinol headgroup relative to the rest of the molecule and was detrimental to potency. As far as pharmacokinetic properties, the dimethyl derivatives $\mathbf{2 0}$ and $\mathbf{2 2}$ both had clearance above $250 \mathrm{~mL} / \mathrm{min} / \mathrm{kg}$ after IV dosing in the rat and provided zero oral bioavailability. The cyclopropyl substituted analogue 25 $\left(\mathrm{pEC}_{50}=9.40\right)$ had good kinetic aqueous solubility $(>400$ $\mu \mathrm{M}),{ }^{23}$ low clearance following IV dosing $(12 \mathrm{~mL} / \mathrm{min} / \mathrm{kg})$, and $80 \%$ oral bioavailability with an oral half-life of $18 \mathrm{~h}$ in rats.

The SAR in the dichloro set (28-34, Table 1) mirrors that of the methyl/chloro series $(35-42)$ with the AR potency in the order $\mathrm{Me}<\mathrm{Et}=$ neopentyl $<$ isopropyl $<$ cyclobutyl $<$ cyclopropyl. Note that going from R1 = ethyl to R1 = isopropyl 
(36 to 37) resulted in an increase in AR potency, but because of the corresponding increase in $\operatorname{cog} \mathrm{P}$, there was no increase in LLE. The alkynyl analogues $\mathbf{3 5}$ and $\mathbf{3 6}$ were designed to probe alternative geometries but resulted in relatively weak $A R$ activity.

In an attempt to drive down the clogP, we turned to small heterocycle substituted analogues (43-54, Table 2). Oxazole 43 gave high $\mathrm{AR}$ activity $\left(\mathrm{pEC}_{50}=8.90\right)$, low lipophilicity $(\operatorname{cog} P=1.22)$, and high ligand efficiency $($ LLE $=7.68)$. This compound also demonstrated excellent drug-like properties with high kinetic aqueous solubility $(>700 \mu \mathrm{M})$, high oral bioavailability (83\%), and $8 \mathrm{~h}$ half-life following oral dosing in rats at $10 \mathrm{mg} / \mathrm{kg}$. Substituents on the heterocycles were generally detrimental to AR potency: several methyl- and dimethyl-substituted heterocycle analogues had little to no AR activity. Likewise, chloro substituents $(47,48$ and 53, 54) were unfavorable to $\mathrm{AR}$ activity, and the higher clogP values, unaccompanied by high $\mathrm{pEC}_{50}$ values, dragged down the LLE values. One of the most potent in the heterocycle series, oxazole 51, demonstrated 500 picomolar AR potency with a $\operatorname{cog} \mathrm{P}=1.67$ and a very high ligand efficiency $(\mathrm{LLE}=7.63)$. This compound also had good drug-like properties including high solubility $(>400 \mu \mathrm{M})$ and $100 \%$ oral bioavailability in the rat with a half-life of $5.5 \mathrm{~h}$.

In summary we have taken advantage of lipophilic ligand efficiency (LLE) as a guide to discover small and drug-like SARMs. The LLE has enabled us to make a distinction between structural changes that increase receptor affinity through nonspecific interactions (i.e., higher lipophilicity) versus changes that are optimal for receptor-specific binding and activation. In the course of this research, we have gone from predecessor compound 5 with an LLE of 4.33 to an optimized analogue (51) with an LLE of 7.63 and discovered novel AR ligands with favorable solubility and pharmacokinetic properties. We will report our progress with identification of a suitable clinical candidate in due course.

\section{ASSOCIATED CONTENT}

\section{S Supporting Information}

The Supporting Information is available free of charge on the ACS Publications website at DOI: 10.1021/acsmedchemlett.5b00377.

Complete description of the AR activity assay, pharmacokinetic study methods, and the synthesis and chemical analysis of compounds 5-121 (PDF)

\section{AUTHOR INFORMATION}

\section{Corresponding Author}

*E-mail: tony.l.handlon@gsk.com.

\section{Present Addresses}

${ }^{\dagger}$ Quintiles, Plaza Building, 4820 Emperor Boulevard, Durham, North Carolina 27703, United States.

${ }^{\ddagger}$ Receptos, Inc. 3033 Science Park Road, Suite 300 San Diego, California 92121, United States.

\section{Notes}

The authors declare no competing financial interest.

\section{ACKNOWLEDGMENTS}

We thank Iris Paulus and Walter Johnson for carrying out the high resolution mass spectrometry analyses.

\section{ABBREVIATIONS}

SARM, selective androgen receptor modulator; LLE, lipophilic ligand efficiency; AR, androgen receptor; DCM, dichloromethane; TBAF, tetrabutylammonium fluoride; HATU, 1[bis(dimethylamino)methylene]-1H-1,2,3-triazolo-[4,5-b]pyridinium 3-oxide hexafluorophosphate; DMF, dimethylformamide; DME, dimethoxyethane

\section{REFERENCES}

(1) Karakelides, H.; Nair, K. S. Sarcopenia of aging and its metabolic impact. Curr. Top. Dev. Biol. 2005, 68, 123-148.

(2) von Haehling, S.; Anker, S. D. Prevalence, incidence and clinical impact of cachexia: facts and numbers-update 2014. J. Cachexia Sarcopenia Muscle 2014, 5, 261-263.

(3) Hughes, V. A.; Frontera, W. R.; Roubenoff, R.; Evans, W. J.; Singh, M. A. F. Longitudinal changes in body composition in older men and women: role of body weight change and physical activity. Am. J. Clin. Nutr. 2002, 76, 473-481.

(4) Mekary, R. A.; Grontved, A.; Despres, J. P.; De Moura, L. P.; Asgarzadeh, M.; Willett, W. C.; Rimm, E. B.; Giovannucci, E.; Hu, F. B. Weight training, aerobic physical activities, and long-term waist circumference change in men. Obesity 2015, 23, 461.

(5) Morley, J. E.; von Haehling, S.; Anker, S. D. Are we closer to having drugs to treat muscle wasting disease? J. Cachexia Sarcopenia Muscle 2014, 5, 83-87.

(6) Brown-Séquard. Note on the effects produced on man by subcutaneous injections of a liquid obtained from the testicles of animals. Lancet 1889, 134, 105-107.

(7) Cadilla, R.; Turnbull, P. Selective androgen receptor modulators in drug discovery: medicinal chemistry and therapeutic potential. Curr. Top. Med. Chem. 2006, 6, 245-270.

(8) Gao, W.; Dalton, J. T. Expanding the therapeutic use of androgens via selective androgen receptor modulators (SARMs). Drug Discovery Today 2007, 12, 241-248.

(9) Steiner, M. S.; Barnette, K. G.; Hancock, M. L.; Dodson, S. T.; Rodriguez, D.; Morton, R. A. Effect of GTx-024, a selective androgen receptor modulator (SARM), on stair climb performance and quality of life (QOL) in patients with cancer cachexia. ASCO Meeting Abstracts 2010, 28, 9147.

(10) Dalton, J. T.; Barnette, K. G.; Bohl, C. E.; Hancock, M. L.; Rodriguez, D.; Dodson, S. T.; Morton, R. A.; Steiner, M. S. The selective androgen receptor modulator GTx-024 (enobosarm) improves lean body mass and physical function in healthy elderly men and postmenopausal women: results of a double-blind, placebocontrolled phase II trial. J. Cachexia Sarcopenia Muscle 2011, 2, 153161.

(11) Basaria, S.; Collins, L.; Dillon, E. L.; Orwoll, K.; Storer, T. W.; Miciek, R.; Ulloor, J.; Zhang, A.; Eder, R.; Zientek, H.; Gordon, G.; Kazmi, S.; Sheffield-Moore, M.; Bhasin, S. The safety, pharmacokinetics, and effects of LGD-4033, a novel nonsteroidal oral, selective androgen receptor modulator, in healthy young men. J. Gerontol., Ser. A 2013, 68, 87-95.

(12) Chekler, E. L. Tissue selective androgen receptor modulators (SARMs): A path to a clinical candidate. Abstracts of Papers, 250th ACS National Meeting \& Exposition, Boston, MA, United States, August 16-20, 2015; MEDI-345.

(13) Study To Evaluate Safety And Tolerability of Single and Multiple Ascending Doses of PF-06260414 in Healthy Western and Japanese Male Subjects. www.clinicaltrials.gov/ct2/show/ NCT02070939 (accessed April 16, 2015).

(14) Product Pipeline. www.pfizer.com/pipeline (accessed July 28, 2015).

(15) Harikrishna, K.; Rakshit, A.; Aidhen, I. S. Study of the chemoselectivity of Grignard reagent addition to substrates containing both nitrile and Weinreb amide functionalities. Eur. J. Org. Chem. 2013, 2013, 4918-4932.

(16) Shidlovskii, A. F.; Golubev, A. S.; Gusev, D. V.; Suponitsky, K. Y.; Peregudov, A. S.; Chkanikov, N. D. A new synthesis of $\mathrm{N}$ - 
substituted-trifluoroacetylanilines. J. Fluorine Chem. 2012, 143, 272280.

(17) Ahvazi, B. C.; Argyropoulos, D. S. 19F Nuclear magnetic resonance spectroscopy for the elucidation of carbonyl groups in lignins. 1. Model compounds. J. Agric. Food Chem. 1996, 44, 21672175.

(18) Walkowiak, J.; del Campo, T.; Ameduri, B.; Gouverneur, V. Syntheses of mono-, di-, and trifluorinated styrenic monomers. Synthesis 2010, 2010, 1883-1890.

(19) Sharma, A. K.; Subramani, A. V.; Gorman, C. B. Efficient synthesis of halo indanones via chlorosulfonic acid mediated FriedelCrafts cyclization of aryl propionic acids and their use in alkylation reactions. Tetrahedron 2007, 63, 389-395.

(20) Cube, R. V.; Vernier, J. M.; Hutchinson, J. H.; Gardner, M. F.; James, J. K.; Rowe, B. A.; Schaffhauser, H.; Daggett, L.; Pinkerton, A. B. 3-(2-Ethoxy-4-phenyl)propanoic acid: a brain penetrant allosteric potentiator at the metabotropic glutamate receptor 2 (mGluR2). Bioorg. Med. Chem. Lett. 2005, 15, 2389-2393.

(21) Murray, C. W.; Erlanson, D. A.; Hopkins, A. L.; Keseru, G. M.; Leeson, P. D.; Rees, D. C.; Reynolds, C. H.; Richmond, N. J. Validity of ligand efficiency metrics. ACS Med. Chem. Lett. 2014, 5, 616-618.

(22) Hopkins, A. L.; Keserue, G. M.; Leeson, P. D.; Rees, D. C.; Reynolds, C. H. The role of ligand efficiency metrics in drug discovery. Nat. Rev. Drug Discovery 2014, 13, 105-121.

(23) Routine kinetic aqueous solubility measurements were carried out at $\mathrm{pH} 7.4$ using a high-throughput method utilizing a chemiluminescent nitrogen detection (CLND) of the test compound in DMSO stock solution. 